\title{
A szakmai könyvklub mint a pedagógusképzés sajátos tanulási környezete
}

\author{
Dobrova Zita'- Szivák Judit ${ }^{2}$
}

${ }^{1}$ ELTE Pedagógiai és Pszichológiai Kar, Neveléstudományi Intézet doktorandusza dzit@student.elte.hu

${ }^{2}$ ELTE Pedagógiai és Pszichológiai Kar habilitált egyetemi docense szivak.judit@ppk.elte.hu

A közös olvasmányfeldolgozás különböző formái, köztük a könyvklubok kiváló lehetőséget nyújtanak arra, hogy a pedagógusok folyamatos szakmai fejlódését annak bármelyik szakaszában támogassák: kapcsolatba kerülhessenek saját gondolataikkal, felismerhessék egy adott pedagógiai helyzettel kapcsolatos érzelmeiket, ráláthassanak viselkedésük, attitüdjük gyökereire, majd felismeréseiket megosztva közös jelentésteremtésbe kezdhessenek. Felen írás elöször a könyvklubok módszertanának elemeit mutatja be, a szakmai könyvklubra mint a pedagógusképzésben is megjelenő, sajátos, progresszív elemeket tartalmazó tanulási környezetre tekint. A jellemzés tizenhat, az utóbbi húsz évben megjelent nemzetközi szakirodalom eredményeinek összegzése alapján készült. A bemutatás kitér arra, hogy ez a tanulási környezet hallgatóközpontú, lehetőséget nyújt a közösségi tudásépitésre, számol az érzelmek és a motiváció szakmai fejlódésben betöltött szerepével, segíti a horizontális kapcsolatok kiépitését a tudáselemek, a tanulási környezet és a tágabb társadalmi környezet között, illetve - végezetül -, hogy sikeresen támogathatja a pedagógushallgatók szakmai fejlódését.

Kulcsszavak: könyvklub, tanulási környezet, pedagógusképzés, szakmai fejlődés

DOI: 10.37205/TEL-hun.2020.1-2.01

\section{Bevezetés}

A tanulmány célja, hogy bemutassa a könyvklubot mint támogató tanulási környezetet. A tanulmány első fejezete azt a módszertant mutatja be, amely alkalmas arra, hogy sajátos tanulási környezetet teremtsen, amelyben megvalósulhat a pedagógushallgatók szakmai fejlődésének támogatása. Az elemzésben a tanulási környezetről mint a Nahalka-definíciónak (2002) megfelelő fogalomról beszélünk: „A tanulási környezet azt a gondolatilag egységes, határozott elméleti alapokon nyugvó, a tanulási folyamatot befolyásoló összes fontos tényezőt magába integráló rendszert jelenti, amelynek keretei között a valóságos iskolai tanulás 
végbemegy." (Nahalka, 2002, p. 95). A könyvklubnak mint optimális tanulási folyamatok keretéül szolgáló környezetnek a bemutatásához pedig az OECD 2010es irányelvei szolgáltak kiindulópontul (Dumont et al., 2010), így ennek során hangsúlyossá válik a tanulási környezet minden résztvevőt fejlődésre sarkalló, egyéni különbségeket is figyelembe vevő hallgatóközpontúsága, a könyvklubokban a csoportos megosztások során megvalósuló társas tevékenység, az érzelmek és a motiváció fontossága, a tanulási folyamat átláthatósága és értékelése, a horizontális kapcsolatok kialakításának lehetősége a képzés más elemeivel, illetve a társadalmi környezettel.

Elemzésünkben összefoglaljuk azt, hogy a könyvklubokban való részvétel milyen tanulási eredménnyel járt az elemzett tizenhat nemzetközi térben megjelent empirikus kutatásokra épülő tanulmányban, végül kitérünk a szerzők által említett nehézségekre, korlátokra is.

\section{A könyvklub}

Mary Kooy több kutatást végzett Kanadában a könyvklubok oktatás terén való felhasználásával kapcsolatban. Tartott könyvklubot diákoknak, kezdő és pályán lévő tanároknak, és könyvet jelentetett meg az utóbbiakkal kapcsolatos kutatási eredményeiről (Kooy, 2006a). A téma szakértői, így Kooy is azt a küldetést is teljesítik, hogy ezt a műfajt a szakmai fejlődés eszközévé, így a tudományos kutatás tárgyává tegyék. A szerzők az általuk pedagógushallgatóknak szervezett könyvklubok résztvevőiről szakmai közösségként, a klubokban zajló folyamatokról pedig a pedagógusképzésben oktatók által tudatosan előkészített és irányított, illetve kísért szakmai fejlődési lehetőségként beszélnek. Ilyen értelemben a könyvklubok sajátos tanulási környezetként jelennek meg ebben a tanulmányban is.

A könyvklubok fogalma alatt a továbbiakban azt a „helyet” értjük, ahol egy közösségben megoszthatóvá, megvitathatóvá és formálhatóvá teszik az olvasmányélmények önálló feldolgozásának eredményeit olyan rendszeres tevékenységek során, melyek dinamikáját az egyéni és a csoportos tudásépítés adja „...olvasás, írás, tanulók által irányított kiscsoportos megbeszélések, megbeszélés az egész osztállyal és instrukció" - fogalmazza meg a módszertan lényegét a könyvklubok keletkezésének történetét, tervezését, mủködését, néhány, diákokkal kipróbált és javasolt technikáját egyaránt röviden bemutató munkában a Raphael és McMahon szerzőpáros (1994, p. 102). A módszer elemeinek kapcsolatát a következő ábrán mutatják be (1. ábra): 


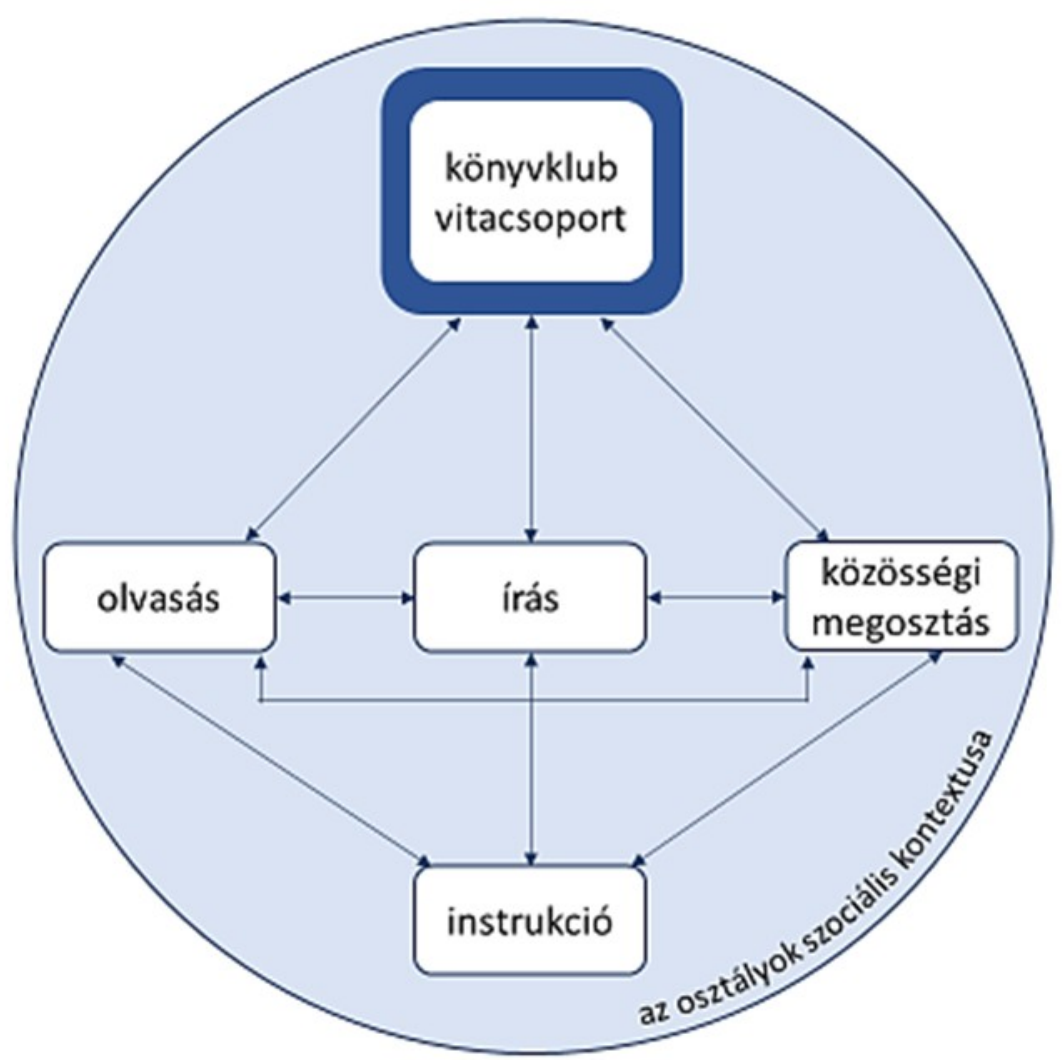

1. ábra: A könyvklub alkotóelemei (Raphael \& McMahon, 1994, p. 104. alapján)

A könyvklubok azon az alapelven működnek, hogy a magányos, sokszor reflektálatlan olvasással megszerezhető és beépíthető tudás megsokszorozódik annak köszönhetően, hogy az olvasottak által keltett gondolatokat és érzéseket a résztvevők rögzítik maguknak, és megosztják egymással. Ez abban az esetben is múködik, ha a csoport tagjai szakirodalmi, elméleti munkákat, illetve akkor is, ha szépirodalmat olvasnak, bár a különböző típusú olvasási helyzetek más-más befogadási stratégiákat indítanak el az olvasóban (Rosenblatt, 1988). Azoknak a csoportoknak, melyek olvasmányélmények közös feldolgozására szerveződnek, jellemzője, hogy a résztvevőknek intellektuális fórumot biztosítanak az olvasmányélmények által keltett gondolatok, érzések megosztásához, megvitatásához. Lehetőséget teremtenek arra is, hogy az olvasottakat egyrészt elemezhessék, reflektálhassanak arra, hogy milyen a befogadási stratégiájuk, másrészt arra is ráláthassanak, hogyan vesznek részt a megosztásban, a beszélgetésben, a közös megvi- 
tatás folyamatában (Flood \& Lapp, 1994a). Az olvasmány feldolgozása során egymást egészíti ki a primer szöveg befogadásának aktusa és az a szövegteremtő (vagy a kifejezésnek más formát adó, például rajzot, képet létrehozó) tevékenység, melyet az olvasmány mellett kérdések, feladatok vagy éppen a többi résztvevő megszólalásai inspirálnak. Az így megszülető szöveg (vagy más végeredmény), a belső beszéd mások számára is érthetővé komponált, aktuális és folyamatosan mozgásban lévő változata lesz, és a meglévő belső tartalom elrendezéséhez, elemzőbb vizsgálatához vezet, majd újabb, későbbi gondolatok alapjává válik, mozgásban tartja a szociális konstrukció teremtő energiáit (Smagorinsky \& O’DonnellAllen, 1998). Mindez segíti a személyes növekedést vagy a szakmai fejlődést támogató tanulási folyamatokat, illetve mélyebb megértéshez, a nézőpontok sokszínúségének felismeréséhez és elfogadásához, gyakran az eredeti álláspont, a vélekedések, előítéletek, attitűdök reflexiókkal kísért megváltozásához vezethet (Flood et al., 1994). Az olvasási tevékenységet szakmai szempontú folyamatba helyezve megerősödik a kognitív, ismeretszerző olvasás szerepe, de a közös megbeszélések alkalmat adnak a saját emlékek felidézésére és azok affektív szempontokkal történő kiegészülésére is (Rosenblatt, 1988). Amennyiben pedig szépirodalmi szöveget vagy visszaemlékezéseket, memoárokat (Hollander, 2001) dolgoznak fel a könyvklub tagjai, mindez felerősödik, a szereplőkkel, a szereplők élethelyzetével való összekapcsolódással a megértés új szintjét érhetik el. Az esztétikai olvasatban rejlő lehetőségek, az ennek a mezsgyéjén haladó olvasói válaszok, a szöveggel folytatott kommunikáció, tranzakció (Rosenblatt, 1988) a belső tartalom gazdagodását eredményezi.

A szövegekkel és a többi résztvevő nézőpontjával való találkozás lehet egyszeri is: egyetlen szakmai vagy irodalmi vita, de az előbb említett eredmények megtapasztalásához a hosszabb folyamat a kedvező. Így jellemzője a klubszerű működésnek a több alkalomból álló, rendszeres találkozás. Az ezeken az (egyszeri vagy többszöri) alkalmakon zajló folyamatot - de olykor a szervezési formát is - az angolszász nyelvterületeken jórészt a book discusse, book talk, book study, group reading kifejezésekkel írják körül. A két legelterjedtebb szervezési forma pedig a könyvklub (book club) és az irodalmi kör ${ }^{1}$ (literature circle) (Daniels, 2006). A közös szövegfeldolgozással kapcsolatos említett kifejezések a nemzetközi irodalomban gyakran egymás szinonimáiként jelennek meg. ${ }^{2}$

${ }^{1}$ A magyar módszertani irodalomban Pethőné Nagy Csilla tette talán legszélesebb körben ismertté ezt a technikát (Pethőné, 2005). 
A pedagóguspálya teljes ívét követhetik a közös beszélgetések szakkönyvekről, szépirodalomról. Az Egyesült Államok élen jár ezeknek a technikáknak az alkalmazásában, számos tanulmány mutat be pályakezdő vagy már jó ideje a pályán lévő pedagógusoknak szervezett szakirodalom-feldolgozással, irodalmi körökkel és könyvklubokkal kapcsolatos kutatásokat. Ezek feldolgozása, a tanulságok öszszegzése későbbi kutatások során hasznos lehet a tanárok folyamatos szakmai fejlődését támogató módszerek gazdagításához, és ahhoz, hogy a technika az iskolafalak között is nagy számban meggyökeresedhessen. „Valami újat keresel az iskolád szakmai fejlődése érdekében? Valamit, amit a kollégáid élvezni fognak, és amiben aktív szerepet vállalnak? Alapíts könyvklubot!”3 (fordítás Dobrova).

\section{A könyvklub mint a pedagógusképzés sajátos tanulási környezete}

A szakmai könyvklubok bemutatott főbb módszertani elemeinek együtthatása, kombinációja komplex tanulási környezet lehet a pedagógusképzésben alkalmazva is. Egy ilyen könyvklub létrehozását természetesen ugyanaz az alapelv vezérli, mint bármilyen egyéb tanulási folyamat megszervezését: olyan feltételeket teremteni, „melyek szükségesek ahhoz, hogy olyan környezetet tudjunk létrehozni és fenntartani, amelyben a tanulási folyamat optimálisan megy végbe." (Szivák, 1988, p. 422).

Az optimális tanulási folyamatokról, tanulási alapelvekkel kapcsolatban a 2010-es OECD-útmutató szempontjai tekinthetők aktuálisan érvényesnek (Dumont et al., 2010), amelyek alapján az olyan tanulási környezeteket tekinthetjük a fejlődést leginkább támogató közegeknek, melyekben lényegi elemmé válik a konstruktív, önszabályozott tanulás támogatása, a tanulás kontextusra való érzékenysége és a kollaborativitás lehetőségének megteremtése. Ezek a tanulás hét alapelvéhez (Dumont et al., 2010, pp. 6-7) a lehető legjobban illeszkednek, azaz

1. a tanulót helyezik a középpontba,

2. szem előtt tartják az egyéni különbségeket,

3. minden tanulót fejlődésre sarkallnak,

\footnotetext{
${ }^{2}$ Jelezzük, hogy alapvető különbség van a szakmai fejlődést támogató céllal létrehozott könyvklubok és a biblioterápiás foglalkozások között, hiszen utóbbiak célja a klinikumban a „könyvekkel történő gyógyítás, könyvgyógyászat” (Jeney, 2012, p. 20), azaz kezelés, a lelki egészség helyreállítása; a klinikumból kilépve, a fejlesztő biblioterápia keretein belül pedig a megelőzés, karbantartás, a lelki jóllét megteremtése, megőrzése, erősítése (Jeney, 2012).

${ }^{3}$ Eredeti szöveg: „Are you looking for something new to do for professional development at your school? Somethig that your colleagues will enjoy and take an active role in? Establishing book club may be just what you're looking for." (Flood \& Lapp, 1994. p. 574)
} 
4. a társas tevékenységet, a kooperációt a tanulás lényegi elemének tekintik,

5. számolnak az érzelmek és a motiváció fontosságával,

6. átláthatóvá teszik és értékelik a tanulási folyamatot,

7. horizontális kapcsolatokat építenek ki a tudás elemei, illetve a tanulási környezet és a tágabb társadalmi környezet, a „világ” között.

A továbbiakban azt vizsgáljuk, hogy a könyvklub módszertanának egy-egy eleme és azok komplex egysége hogyan felel meg ennek a hét szempontnak. Az első hármat egy tartalmi egységen belül vizsgájuk.

\section{Középpontban a hallgatók}

A könyvklubokban folyó munka első fázisa az elmélyült individuális tevékenység, az olvasmányokkal kapcsolatos személyes tartalom felfedezése, a szövegek reflektív feldolgozása, az olvasó önálló jelentésteremtése, tudáskonstrukciója. Ez a tevékenység a hallgató otthoni, személyes tanulási környezetében vagy más, általa megválasztott tanulási környezetben zajlik, és jellemzően írás kíséri: emlékek, gondolatok, kérdések, első személyes reflexiók rögzítése.

„Az olvasásnak mint jelentéskonstrukciónak az értelmezése azt jelenti, hogy az olvasó olvasás közben teljes személyiségével, kognitív és affektív tartalmaival vesz részt a saját megértési folyamataiban, személyes kontextusba vonja és reflektálja az olvasottakat. Ehhez a jelentésteremtési folyamathoz használja előzetes ismereteit, jelentésekben, struktúrákban szerveződő kognitív sémáit, és ha az olvasott szöveg tartalma ezt lehetővé teszi, akkor - feltételezhetően - a korábbi tapasztalataiból származó, nézeteknek tekintett pszichikus konstrukcióit." (Dudás, 2007, p. 88).

A pedagógusképzésben szervezett könyvklubokat dokumentáló szerzők csoportjaiban alapvetően szakirodalmi szövegeket dolgoztak fel a résztvevők (Moore 2008; Hall, 2009; Mensah, 2009; Burbank et al., 2010; Robertson \& Smith, 2017)

A könyvklubfolyamat középpontjában a hallgató áll, most még magányosan, ez a szakasz az egyéni tudáskonstrukciónak és az érzelmek megjelenésének, tanulásra motiváló erejének fázisa is. A szövegek információszerző olvasása a kognitív folyamatokkal, az esztétikai, az affektív belső világgal köti össze a befogadót. Bármilyen jellegű szöveget is választottak a könyvklub megtervezői, mindkét folyamat elindult, ha nem is rögtön a szöveg olvasásakor, de az egyéni írásos, reflexiós, esetleg alkotói szakaszban, vagy ha még akkor sem, akkor a közös megbeszélések, a saját emlékek, tapasztalatok mozgósítása során bizonyosan (Burbank et al., 2010; Robertson \& Smith, 2017). 
A hallgatók egyéni különbségeihez, személyes preferenciáihoz a könyvek kiválasztásának (kisebb vagy nagyobb mértékű) szabadságával igazodtak az oktatók, bár a szövegek kiválasztását, de legalábbis ennek előkészítését általában a saját joguknak tartották. ${ }^{4} \mathrm{Az}$ oktatók a műválasztás irányítását azért is tarthatták saját hatáskörben, mert maga a mü a fó szervezőeleme annak a pedagógiai folyamatnak, melyet a könyvklubbal támogatni kívántak, tehát az általuk meghatározott pedagógiai célnak megfelelően válogatták ki a feldolgozandó olvasmányokat. A legfőbb szempont általában a mủ relevanciája, mert olyan művet érdemes választani, amely egy adott problémát jól reprezentál (Batchelor et al., 2018).

A hallgatót a folyamat középpontjába helyező szándék a könyvklubok irányításában is tetten érhető. A klubok vezetését jellemzően az oktató végezte, akinek jobbára facilitáló-mentoráló szerepe több szerző tanulmányában jól körvonalazódik (Hall, 2009; Mensah, 2009; Burbank et al., 2010; Skerrett, 2010; Kesler, 2011; Scheffel et al., 2018). Az oktató szerepét ezzel együtt szükségesnek látták ahhoz is, hogy olyan biztonságos közeg alakuljon ki a csoportban, mely a megszólalásokat támogatja, és oldja a résztvevők személyes dolgok megosztásával kapcsolatos félelmét (Stanulis, 1999). Smagorinsky és munkatársai szerint (2015) a tanár szerepe főleg az, hogy megtervezze azokat a tevékenységeket, amelyek során a hallgató kialakíthatja a saját koncepcióját az adott problémával kapcsolatban. Tanulmányukban a konstruktív tanuláshoz illeszkedő „állványozás” metaforát használják (Wood et al., 1976), mely optimális esetben szükséges és éppen elégséges támogatás nyújtása a tudásépítésben részt vevő számára egy új szint, emelet megalkotásához. A sikeres támogatásnak azonban fontos kritériuma, hogy az oktató a tudásépítést ne vegye át, ne uralja, csak segítse, hogy senki ne tehesse fel azt a kérdést, hogy „Ez végül is kinek az épülete?” (Searle, 1984). Megoldást jelenthet, ha az „állványozás” nem egyetlen tanulási helyzetben zajlik, hanem „megosztott”. A tanulmányban szereplő konkrét csoport esetében e tevékenységek sokfélék voltak: saját diákéletükből és a társadalomból származó elsődleges tapasztalatok, melyek kritika tárgyai voltak a képzésben szerveződő kurzuson; egy alternatív iskolában szerzett tapasztalatok (a tanterv, a gyermekkel való kapcsolatok, a kollé-

${ }^{4}$ Felicia Moore Mensah csoportjában (Moore, 2008; Mensah, 2009) a klub az általa kiválasztott művet dolgozta fel, más klubokban a vezetők jellemzően elég bő listákat készítettek, melyekről aztán a résztvevők választhattak (Hall, 2009; Burbank et al., 2010; Batchelor et al., 2018). Több nagyobb létszámú klubban pedig a választások alapján kisebb csoportok szerveződtek (Rogers \& Mosley, 2008; Marable et al., 2010; Robertson \& Smith, 2017). Volt olyan könyvklub is, melynek az első tanévében az oktató, a másodikban már a résztvevők állították össze az olvasandó művek hét elemből álló listáját (Scheffel et al., 2018). 
gák); az egyéni olvasás; a könyvklubban a hallgatók által vezetett kiscsoportos megbeszélések; és a teljes csoportos megbeszélések, melyeket szintén úgy irányítottak, hogy mentesek legyenek az oktató direkt hatásától (Smagorinsky et al., 2015, p. 74.).

A könyvklubokban a korábban már bemutatott egyéni munka mellett kiscsoportos és teljes csoportos diskurzusok is folynak. A kiscsoportos megosztásokat a hallgatók maguk koordinálják, és jellemzően egy közös produktummal, reflektív írással zárják. Scheffel és társai részvételi akciókutatásában (Scheffel et al., 2018) tetten érhető a hallgatók egyre nagyobb mértékű felhatalmazása, melynek köszönhetően kutatótársakká is váltak: nemcsak a művek kiválasztásában, hanem a kurzus előkészítésében, majd a kétéves folyamat második évében facilitátorokként a klubok üléseinek vezetésében is aktív szerephez jutottak, részt vettek az adatok feldolgozásában, végül szerzőtársak lettek a tanulmány megírásában. Stover és munkatársai egy olyan online könyvklub müködését elemzik, ahol hallgatók diákokkal együtt vettek részt a könyvekről való közös gondolkodásban. Ebben a formában a pedagógushallgatók a diskurzusban kis csoportokat animáló, strukturáló szerepet is kaptak, azaz miközben az olvasás és a megosztás során saját tudásukat építették az adott témáról, a facilitátor-pedagógus helyzetét is átélhették, gyakorolhatták (Stover et al., 2016).

A tanulmányokban a könyvklubok sokfélesége jelenik meg, mely hallgató- és tanulásközpontúságával, a felhatalmazás különböző fokával, a tapasztalatszerzés változatos formáival is fejlődésre, az egyéni tanulási úton való folyamatos haladásra sarkall.

\section{Társas tevékenység, kooperáció, kollaboráció}

Mary Kooy kezdő és pályán lévő tanároknak szervezett klubjaival kapcsolatos kutatási eredményeit összefoglaló könyvében (Kooy, 2006a) és a kezdő pedagógusokkal való munkájáról szóló tanulmányában (Kooy, 2006b) is hangsúlyozza a könyvklubok három sajátosságát: a narratíváknak és a tudásnak; a nyelvnek és a közösségnek; valamint a közösségnek és a tanulásnak a kapcsolatát. Könyve elméleti hátterében ezt a hármasságot a szociális konstrukció, a dialogikusság és a narrativitás pilléreire építi. A könyvklubok erejét a közösségi történetmegosztásban látja.

A hallgatók által egyénileg felidézett, rögzített, reflektált belső tartalmaknak a megosztása hatványozza a módszertan erejét. Felerősíti azokat a kérdéseket, melyeket a hermeneutika tételei szerint a művek tesznek fel a befogadónak, és pár- 
beszédbe vonja azokat az egyéni válaszokat, melyeket az egyes befogadók ezekre adnak. A megbeszélések, a nézőpontok megismerésének, ütköztetésének lehetősége kimozdítja a résztvevőket saját értelmezésükből, és a kollektív, kollaboratív forma, a közös tudásépítés utat nyit a gondolatok szárnyalásának. A mélyebb megértés megszületésében a szerzők rendkívüli szerepet tulajdonítottak a csoportos kommunikációnak: „minden interakció annak a lehetőségét rejti magában, hogy a résztvevők új jelentést teremtsenek” (Rogers \& Mosley, 2008, p. 127).

A közös megbeszélések során megfogalmazódhatnak és formálódhatnak az egyéni narratívák, melyek a szakmai identitás aktuális manifesztációi lehetnek. Emellett a csoportokban a hallgatók találkozása a saját maguk által alkotott szövegek találkozása is, a közösség egyfajta tanulást generáló „szövegközösséggé” válhat (Bruner, 2004, p. 62). A közösségi élmény erejének hatását rengeteg szöveghely támasztja alá a tanulmányokban. Fontos pontjai ezeknek, hogy a közös munka a felületes olvasásnál mélyebb, reflektívebb folyamat volt (Burbank et al., 2010), mely által közösen konstruált tudás jelent meg a csoportban (Robertson \& Smith, 2017; Scheffel et al., 2018), és amelyet a résztvevők kimondottan értékeltek (Marable et al., 2010; Robertson \& Smith, 2017). Burbank és munkatársai (2010) a könyvklubban zajló tanulási folyamat (Hall és Mensah által is kiemelt) közösségi jellege mellett aktív jellegére is felhívják a figyelmet.

A könyvklubokban végeredményben egyéni, kollaboratív és kollektív tanulás zajlott (Mensah, 2009), a közösség tanulóközösséggé vált (Skerrett, 2010), a tudás szociális konstrukció terméke lett, a csoportokban zajló eszmecsere során az egyéni olvasói válaszok nem statikus formába merevedtek, hanem egy folyamat részei lettek, amelyben folyamatosan változtak, alakultak (Kesler, 2011). A tanulóközösség jelleget Kooy is hangsúlyozza említett könyvében (Kooy, 2006a), de ezt emeli ki Robertson és Smith (2017) is, és hozzáteszi, hogy a könyvklubok tapasztalata azért is fontos a hallgató számára, mert megtanulhatja, hogyan kell az ilyen tanulóközösségekben részt venni, bízva abban, hogy később a kollegái körében is hasonló módon szerez majd tudást. A könyvklubban alkalmazott szociálkonstruktivista megközelítés több tanulmányban expliciten hangsúlyos. Hall a klub közösségében tanulást állandóan mozgásban, átalakulásban lévő folyamatnak tartja, melyben a szöveg által előhívott reflexiók, egyéni nézőpontok kiegészülnek a csoportos beszélgetések során megszülető nézőpontokkal, a belső tartalmak, gondolatok nyitottak, párbeszédbe vonhatók vagy megvizsgálhatók, és mindig újabb jelentéssel bővülhetnek (Hall, 2009). 
A csoportokban való részvétel a sokféleséggel való találkozás megtapasztalásává is vált: a csoportok vagy a klubon belüli kis csoportok megkomponálásában az oktatók gyakran tudatosan éltek azzal az eszközzel, hogy eltérő nemű, korú, szociális hátterű, bőrszínű vagy adottságú hallgatók dolgozzanak együtt. A résztvevők segítették, támogatták egymást az interakciók során a későbbi, multikulturális környezetben szükséges készségek fejlesztésében (Rogers \& Mosley, 2008), és így nemcsak az olvasmányokon keresztül, hanem a valódi közösségben is felismerhették, hogy a sokféleség „értékes tapasztalatok gyűjteménye” (Mensah, 2009, p. 1052).

A közös megbeszélések a kritikai és reflektív gondolkodás fejlesztésére is alkalmat adtak (Mensah, 2009). A reflektív szemlélet, reflektív gondolkodás, reflektív gyakorlat a pedagógus életpályáját végigkíséri, és a szakmai fejlődést támogatja (Schön, 1983; Falus, 2006; Szivák, 2014). Ehhez jó tanulási terepet nyújtottak az egyéni és a csoportos, kollektív reflektív helyzetek (Collin \& Karsenti, 2011). A felvetett problémáktól függően a résztvevők a kritikai reflexiók területén is jártasságot szereztek (Brookfield, 1995). Az oktatók sok esetben változatos, reflektív gondolkodást fejlesztő technikákat használtak, például a vitát, szerepjátékot (Batchelor et al., 2018), kritikus barát módszert (Burbank et al., 2010), „virtuális” hangos gondolkodást (Stover et al., 2010), reflektív esszét (Roger \& Mosley, 2008), kollektív reflektív olvasónaplót (Scheffel et al., 2018).

\section{Az érzelmek és a motiváció}

A könyvklubok üléseire való felkészülésben, az olvasás és a reflektív írások elkészítése alatt, illetve a közös munka során is hangsúlyos a szakmai fejlődés és az érzelmek kapcsolatának felismerése.

Az érzelmek mozgósításának és feltérképezésének fontos eszköze maga az olvasmány lehet. A szépirodalom vagy a memoárok vagy azok a szakirodalmi szemelvények, amelyek anekdotikus elemet, történetté formálódó narratívát tartalmaznak, könnyebben teremtették meg a kapcsolatot az olvasó és a mủ, a fikció és a saját tapasztalat között, hogy aztán a reflektív szakaszokban ezek együtt fogalmazódjanak meg. Számos olyan felismerésről olvashatunk a tanulmányokban, amikor a résztvevőkben megszületett a szereplőkkel való rokonság, hasonlóság, vagy a szereplők élethelyzetét, problémáit könnyen tudták saját példákkal vagy a gyakorlaton tanított diákok példáival szinkronizálni (Stanulis, 1999; Marable et al., 2010). 
A szépirodalmi szövegek erejével kapcsolatban érdemes Stanulis (1999) néhány gondolatát kiemelni. Az általa leírt könyvklubban ifjúsági irodalmat olvastak a hallgatók, és ez részben a saját kamaszkorukkal, részben azoknak a diákoknak a világával kapcsolta össze őket, akiket majd tanítani fognak. A fikción keresztül a hallgatók erős érzelmekkel tudtak kötődni a kamaszkorhoz és a kamaszokhoz, az olvasmány megteremtette annak a lehetőségét, hogy a karakter szemével lássanak, vele érezhessenek, és az volt a tapasztalat, hogy az érzelmi komponensnek köszönhetően a hallgatók világa kinyílt, az olvasás virtuális tapasztalattá vált. Fontos meglátása a szerzőnek még az is, hogy a fiktív szereplők fiktív helyzetein keresztül sokkal könnyebb volt érzékeny témákat megvitatni, az irodalmi mű védelmet biztosított a megszólalónak.

Az élmény közösségi természete sokkal elkötelezettebbé tette a résztvevőket a megvitatás és a szöveg mélyebb megértésének szándékában (Stover et al., 2016). A folyamatot sokszor az empátia megélése, az elfogadottság, a bizalom és a tisztelet érzései kísérték, a pozitív érzelmek a motivációt is fokozták. Motiváló erő rejlik a klubvezető által megteremtett, már említett bizalmi légkörben is, a jól megválasztott könyvek körének kijelölésében, a műválasztás felkínálásában és a kiscsoportos megbeszélések önálló irányításában is.

\section{A tanulási folyamat átláthatósága és értékelése}

A hallgatók a klubokba való belépésükkor és később az egész munka során tudták, hogy mi fog történni a foglalkozásokon, illetve hogyan és miért válik ez a tevékenység is a szakmai fejlődésük részévé.

A módszertan egyes elemeinek szoros összefüggése ezt az átláthatóságot erősítette, a klubfoglalkozások pedig folyamatosan annak a fórumává is váltak, hogy ki hogyan halad az adott témával vagy problémával kapcsolatos belső munkájában: hasznos volt, ha reflektáltak a saját múködésükre. A reflektivitás már korábban bemutatott szerepe mellett az is kulcsfontosságú volt, hogy a résztvevők olvasóként is megfigyelhették és elemezhették magukat (Robertson \& Smith, 2017), de ugyanígy a csoportmunka résztvevőiként is megfigyelhették magukat, reflektálhattak a szerepükre (Scheffel et al., 2018).

A csoportban a nézetek, gondolatok ütköztetése a tanulási folyamat során megtett közös és egyéni út értékelésére is alkalmat adott. A kutatások egy részében ezeknek az eredményeknek az egyéni és csoportos értékelése fontos adatforrássá is vált (Moore, 2008; Rogers \& Mosley, 2008; Hall, 2009; Mensah, 2009; Burbank et al., 2010; Marable et al., 2010; Robertson \& Smith, 2017). 


\section{Horizontális kapcsolatok}

A pedagógusképzéshez kapcsolódó könyvklubok rendszerint a formális oktatás részei, valamilyen kurzuson belül szerveződnek, de legtöbbször szoros összefüggésben vannak más kurzusokkal a Marable és társai (2010) által elemzett könyvklub például egy módszertani kurzus része volt, melyet értelmi sérültek körében végzett szakmai gyakorlat is kiegészített), összekapcsolódhatnak más tanulási alkalmakkal (Rogers \& Mosley, 2008; Skerrett, 2010; Kesler, 2011; Smagorinsky et al., 2015;), gazdagítják a differenciált élmények sorát, melyek a képzésben és a pályán folyó szakmai fejlődésben is fontosak (Burbank et al., 2010). Ilyen komplexitás része volt a könyvklub például a missouri egyetemi csoportban (Rogers \& Mosley, 2008), ahol a szemináriumi munka, az olvasás, az online viták, a naplóba írt reflexiók, a tanítási tapasztalatok, a kollégákkal folytatott, tanítással kapcsolatos beszélgetések és a könyvklubokon folyó megbeszélések együtt teremtettek a tanárhallgatók számára lehetőséget arra, hogy rasszizmusról, antirasszizmusról való tudásukat bővítsék, nézőpontjukat, attitűdjüket vizsgálják, illetve azt is megtanulják, hogyan vegyenek részt vitában, párbeszédben erről a témáról.

Arra is találunk példát, amikor a könyvklubok a felsőoktatáson belül, de már a kurzusok kötöttségéből kilépve kínálnak lehetőséget a szakmai fejlődésre (Batchelor et al., 2018; Scheffel et al., 2018). Scheffel korábbi kurzusának hallgatóiból alakult ki például az a könyvklub, mely még két éven keresztül müködött, immár mindenféle hivatalos keret, kötelezettség nélkül.

A hallgatók épülő tudásának forrásai sokfélék lehetnek, és a könyvklub nem pusztán egy lesz ezek közül, hanem olyan fórummá válhat, ahol a résztvevők informális vagy implicit tudása is a felszínre kerül, tudatosodik, s így feldolgozhatóvá, értékelhetővé válik. Például az olyan családból, korábbi tapasztalatokból, kortárs közösségekből vagy akár a médiából származó nézetek, magatartásminták, melyek befolyásolják szakmai fejlődésüket, tanárszereppel kapcsolatos elképzeléseiket, későbbi szakmai döntéseiket vagy éppen a tanulókkal kapcsolatos magatartásukat, attitűdjüket.

A könyvklub müködésében könnyen tetten érhető tehát, hogy az optimális tanulási környezet horizontális kapcsolatot épít ki a különböző tudáselemek között - az egymás mellett megjelenő, egymás mellé rendelődő, különböző területekről származó tapasztalatok, ismeretek válnak egy új struktúra egymást erősítő részeivé -, illetve nyit a tágabb társadalmi környezet, a világ felé. Hiszen a könyvklubokban gyakran valamilyen társadalmi kérdéssel, problémával kapcsolatos néze- 
tek, elóítéletek, vélemények, attitűdök, aggodalmak stb. kerülnek a középpontba, például szociális különbségek (Stanulis, 1999; Felicia Moore Mensah könyvklubja: Moore, 2008, Mensah, 2009; Smagorinsky et al., 2015), a rasszizmus (Mosley és Rogers könyvklubja: Rogers \& Mosley, 2008; Mosley, 2010; Mosley \& Rogers, 2011) vagy a másság problémaköre (Batchelor et al., 2018), melyekkel a hallgatók később találkozni fognak a pályájukon: „[...] fel kell ismerni, hogy a tanárképzésnek fejlődnie kell. Itt az idő, hogy feltegyünk magunknak néhány nehéz, kényelmetlen kérdést. Bevalljuk végre, hogy a rasszizmus, alkoholizmus, szexizmus létezik, vagy még mindig azt tettetjük, hogy nincs jelen az amerikai kultúrában és az iskolai életben?" (Harlin et al., 2007, p. 299).

A belső tartalmak, az olvasmányélmények, illetve a majdani társadalmi vagy iskolai kontextus között teremtenek kapcsolatot más témájú könyvklubok is: például az, amelyik középsúlyos és súlyosan értelmi fogyatékosokkal való foglalkozásra történő felkészítés részét jelentette a New York-i gyógypedagógus-képzés egy kurzusán (Marable et al., 2010). Hasonló példa Hall (2009) klubja, amely a hallgatók szakmai öndefiníciójának megalkotását támogatta egy olyan tanári munkához, mely szociokulturális és szocioökonómiai kérdések feszültségével teli társadalmi környezetben valósul majd meg.

A pedagógusképzésben nemcsak a részletesen bemutatott, hagyományosabb könyvklubok jelennek meg, hanem az online könyvklubok is, melyekben a horizontális kapcsolódás lehetőségei tovább tágulnak.

Ahhoz, hogy ezek speciális jellegét meghatározzuk, a tanulási környezetek bemutatását, tipologizálását a technika fókuszából is meg kell tennünk. A 21. századi tanuló-hallgató számára lehetőségként fennálló komplex tanulási környezetet a digitális technika jelentős mértékben átitatja. Ha minden eddig elemzett könyvklubot ilyen aspektusból vizsgálnánk, valószínű (a tanulmányokban ezzel kapcsolatban nem mindig áll rendelkezésre elég információ), hogy hálózattal támogatott kontakt tevékenységről beszélhetnénk. Az online könyvklubok esetében nem pusztán online oktatási környezetben zajlik a tanulás, hanem kiegészül kontakt oktatási környezetben folyó tevékenységgel is, amely így hibrid oktatási környezetet eredményez (Lévai, 2014).

Az online könyvklubok sajátos helyet foglalnak el a pedagógusképzés keretében szervezett könyvklubok között. A digitális technika, az internet vizuális világa, az írás-olvasás, a szövegértés-szövegalkotás általában véve a kommunikáció vagy a műveltség fogalmának kitágított értelmezését kívánja, melybe a hagyomá- 
nyos formákon kívül például a blogírás, a videóchatelés, az infografikák készítése, a digitális történetmesélés is hangsúlyosan beletartozik (Stover et al., 2016). Az interneten a tudásépítés és a szakmai élményszerzés izgalmas új formái képzelhetők el, a kollaboráció, a kommunikáció és a közösség új jelentést kap, de könnyen alakítható ki olyan virtuális csoport is, melyben a pálya különböző szakaszain levők, vagy más szerepben levők (gyakorlatukat végző hallgatók, diákok) gondolkodhatnak együtt (Stover et al., 2016).

Stover és munkatársai szerint az online könyvklub forma valódi, odafigyelő meghallgatást, megnövekedett gondolkodási időt, magasabb fokú motivációt és elköteleződést biztosított. A meghosszabbodott gondolkodási időnek köszönhetően megszabadultak a résztvevők az azonnali visszajelzés kényszerétől, nyomásától, feszültségétől, és ha már kialakult a véleményük, azt később is el tudták olvasni, bármikor vissza tudtak rá térni, dokumentálhatták a változást is, változtattak nézőpontjukon vagy véleményükön. Míg az ülések egy hagyományos, személyes részvételen alapuló könyvklubban egy meghatározott térben-időben, véges keretek között valósulnak meg, az online platform előnye az is, hogy nem csak egyszer egy héten, és nem csak az adott ideig lehet kapcsolódni a témához és a csoporttársakhoz (Stover et al., 2016).

\section{Tanulási eredmények}

A hallgatók számára a könyvklubok sajátos tanulási környezete fejlődésre sarkalló közegnek bizonyult, jól szolgálta az oktatók pedagógiai céljait. A hallgatók a tanulmányokban foglaltak szerint könyvklubokban való részvétel közben személyesen is, szakmailag is fejlődtek. Erősödött bennük a fejlődés, tanulás igénye (Mensah, 2009; Scheffel et al., 2018), az élethosszig való tanuláshoz és olvasáshoz való kedv, valamint az ezekre való képesség. Felismerték, hogy az olvasó tanár minta és példa (Robertson \& Smith, 2017). Jobban látták a könyvek felhasználhatóságának a lehetőségeit, gyarapodtak módszertanukat illetően (Kesler, 2011; Scheffel et al., 2018). Pontosabb képpel rendelkeztek a folyamat végén az iskoláról, a tanárszerepről (Hall, 2009; Smagorinsky et al., 2015; Robertson \& Smith, 2017), a gyerekek közösségéről, melyben nekik szerepük, feladatuk lesz (Moore, 2008, 2009; Rogers \& Mosley, 2008; Marable et al., 2010; Mosley, 2010; Mosley \& Rogers, 2011). Gyakran érték el a megértés mélyebb szintjét az adott problémakörrel kapcsolatban (Rogers \& Mosley, 2008; Mensah, 2009), többször nézőpontjuk (Marable et al., 2010), olykor nézeteik is változtak (Rogers \& Mosley, 2008; Mensah, 2009). Remek kiegészítésévé vált a forma a hagyományos tanítási gyakorlatnak, a hall- 
gatók komfortosabban érezték magukat a tanárszerepben vagy például az értékelési helyzetekben.

A szakmai területen megragadható eredmények, változások, gyarapodás mellett több szerző is kitért arra, hogy a könyvklub hozzájárult a pedagógushallgatók személyes fejlődéséhez, például az önismeret (Scheffel et al., 2018), az empátia, a tisztelet és a kölcsönös tisztelet terén (Marable et al., 2010), a résztvevők megtanultak jobban figyelni a másik emberre (Stover et al., 2016), és intellektuálisan is gazdagodtak (Rogers \& Mosley, 2008). Egy esetben a kutatók az írói alkotókedv megerősödését is dokumentálták (Scheffel et al., 2018).

\section{A könyvklubokban folyó munka korlátai}

A tanulmányok egy részében természetesen megjelennek olyan problémák, amelyek megnehezítik a könyvklubok sikeres tanulási környezetként történő működését. Míg a felvetett témák, az olvasott szövegek (különösen a szépirodalmi művek) a hallgatók többségét könnyen bevonták a sajátos tanulási folyamatba, voltak példák a kívülmaradásra is.

Magával a problémával, a könyvklubokat szervező nagy központi gondolattal való nehezebb azonosulás (vagy éppen a túlságos érintettség) például eleve viszszatartó erő lehetett. Ilyen téma volt például a sokféleség elfogadása. Scheffel és társai azt tapasztalták, hogy a könyvklubban zajló munkát, kinek-kinek a bevonódását már ez a kiindulópont is befolyásolhatta, nem egyformán szívesen kapcsolódtak a problémához, nem mindenkinek volt megközelíthető ugyanolyan módon, ugyanolyan könnyen, ugyanolyan szinten vagy ugyanolyan ütemben (Scheffel et al., 2018).

Scheffel és munkatársai (2018) azt is megfogalmazták végső konklúzióként, hogy ez a technika nem való mindenkinek. Hall (2009) úgy látja, hogy a könyvklub lehetőség, tér az átgondoláshoz. Batchelor és munkatársai (2018) szerint sem biztos, hogy az olvasás később, a tanítás során majd megváltoztatja a hallgatókat, de az, hogy megismernek más perspektívákat is, elindíthatja őket a nézetformálás irányába. 


\section{Összegzés}

A könyvklubok által létrehozott tanulási környezet a pedagógusképzésben sikeresen támogathatja a hallgatók szakmai fejlődését. A módszertan röviden bemutatott elemei egyenként is lehetőséget nyújthatnának erre, de a valódi erejüket elsősorban a kombinációjuk, illetve a foglalkozások hangsúlyozott közösségi jellege adja.

Az individuális olvasás - a mű és befogadó tranzakciója - során a szakmai vagy irodalmi szövegek jó kiindulási pontként szolgálnak ahhoz, hogy a hallgatók értelmezni, elemezni kezdjenek pedagógiai helyzeteket, problémákat. Ezeket a kognitív folyamatokat gyakran érzelmek is kísérik, főképp szépirodalmi szövegek olvasása során. A foglalkozásokat megelőző egyéni szövegfeldolgozás alkalmat ad a saját tapasztalatok, emlékek átgondolására, elemzésére, ezáltal a saját értelmezés kialakítására, és közelebb visz a szakmai identitás kialakításához, a nézetek, érzelmek feltárásához, fejleszti a reflektív gondolkodást. A könyvklubban folyó kiscsoportos munka már a közös, kollaboratív tudásépítéshez, a reflektivitás kollektív formájának gyakorlásához ad keretet, és ez többszöröződik meg a teljes csoportban való munka során, mellyel a horizontális kapcsolódási pontok is megsokszorozódnak. Ezért értékek, célok, saját tapasztalatok, nézetek, érzelmek megosztása, ütköztetése a csoportos kommunikáció során olyan lehetőség, mely az egyéni feldolgozás tanulságait új fénytörésbe helyezheti, mélyebb megértéshez vezethet. A csoportban zajló munka során számos emberi érték is erősödik. A könyvklubban szerzett tapasztalat gazdagítja a hallgató módszertanát, és kedvet, illetve mintát adhat a későbbi szakmai közösségekben való részvételhez.

A könyvklubok sajátos tanulási környezetében komplementer (tradicionális és progresszív jelleget egyaránt mutató) tanulási környezet épül (Komenczi, 2009), de a tradicionális tanulási környezet jellemzői szinte kizárólag a formális keretek megteremtésében érhetők tetten (például egy felsőoktatási kurzus órakeretei, részben „osztálytermi” környezet, a tanulási folyamat előre tervezése, a választható olvasmányok kijelölése). Müködés közben azonban jól azonosíthatók progreszszív elemek (Komenczi, 2009, p. 72): a hallgatók önálló tudásépítését összetett és tanulásra sarkalló, inspiráló tanulási környezet támogatja; a tudás konstrukciójába integrálható elemek különböző perspektívából és forrásból származnak; a tanulási folyamat támogatja készségek, kompetenciák, jártasságok, attitűdök, köztük az egész életen át történő tanulásra való képesség és készség kialakítását; a 
könyvklubban zajló munka lehetőséget nyújt akár projektek kivitelezésére is. A tanulás a könyvklubok tagjai számára jobbára élvezetes, érdekes; az egyéni és teljes csoportos forma mellett kisebb csoportok is szerveződhetnek; heterogén korcsoportban történhet tanulás; az innovatív tanulási folyamatot kreativitás és kritika kíséri; a csoportmunkát a résztvevők belső szabályok alapján irányítják (Komenczi, 2009, p. 71).

A bemutatott módszertan talán inspiráló lehet a hazai pedagógusképzés számára is. A szakmai fejlődést a képzés bármelyik szakaszán sikeresen támogathatja, de két pontján különösen erős lehet a hatása. A belépő hallgatók számára keretet nyújthat a hétköznapi pedagógiai nézetek feltárásához, a szakmai identitás építésének első lépéseihez. Illetve ahogy a bemutatott tanulmányok egy részében is láthattuk, a tanítási gyakorlaton részt vevő hallgatók számára szintén hasznos közösség, értékes támogatás lehet, hiszen a képzésben megszerzett ismeretek és a közoktatásban immár a pedagógus oldaláról szerzett konkrét tapasztalatok, a pedagógusszereppel kapcsolatos új dilemmák, érzések, viszonyulások elemzésére, a különböző nézőpontok, vélemények ütköztetésére is lehetőséget nyújt, kiegészítheti az oktatók, mentorok munkáját egyaránt. 
Pedagógusképzés • 19(47), 2020/1-2.

\section{Irodalom}

Batchelor, K. E., Ramos, M. \& Neiswander, S. (2018). Opening Doors: Teaching LGBTQ-themed Young Adult Literature for an Inclusive Curriculum. The Clearing House, 91(1), 29-36. DOI: 10.1080/00 098 655.2017.1366183

Brookfield, S. D. (1995). Becoming a Critically Reflective Teacher. Jossey-Bass.

Bruner, J. (2004). Az oktatás kultúrája. Gondolat Kiadó.

Burbank, M. D., Kauchak, D. \& Bates, A. J. (2010). Book Clubs as Professional Development Opportunities for Preservice Teacher Candidates and Practicing Teachers: An Exploratory Study, The New Educator, 6(1), 56-73.

DOI: 10.1080/1547 688X.2010.10399588

Collin, S. \& Karsenti, T. (2011). The collective dimension of reflective practice: the how and why. Reflective Practice, 12(4), 569-581.

DOI: $10.1080 / 14623943.2011 .590346$

Daniels, H. (2006). Literature Circles. Voice and Choice in Book Clubs and Reading Groups. Stenhouse Publishers.

Dudás, M. (2007). Tanárjelöltek belépő nézeteinek feltárása. In Falus, I. (Ed.), A tanárrá válás folyamata (pp. 46-121). Gondolat Kiadó.

Dumont, H., Istance, D. \& Benavides, F. (2010). The Nature of Learning, Practitioner Guide from the Innovative Learning Environments Project. OECD http://www.oecd.org/education/ceri/50 300 814.pdf (2020. 01. 14.)

Falus, I. (2006). A tanári tevékenység és a pedagógusképzés új útjai. Gondolat Kiadó.

Flood, J. \& Lapp, D. (1994). Issues and Trends: Teacher Book Clubs: Establishing Literature Discussion Groups forTeachers. The Reading Teacher, 47(7), Literacy in the Content Areas: New Definitions and Decisions for the 21st Century (Apr., 1994), 574-576. https://www.jstor.org/stable/20 201319 (2019. 08. 26.)

Flood, J., Lapp, D., Alvarez, D., Romero, A., Ranck-Buhr, W., Moore, J., Jones, M. A., Kabildis, C. \& Lungren, L. (1994). Teacher Book Clubs: A Study of Teachers' and Student Teachers' Participation in Contemporary Multicultural Fiction Literature Discussion Groups. Reading Research Project, No. 22.

https://files.eric.ed.gov/fulltext/ED379597.pdf (2019. 08. 26.)

Hall, L. A. (2009). "A Necessary Part of Good Teaching”: Using Book Clubs to Develop Preservice Teachers' Visions of Self. Literacy Research and Instruction, 48(4), 298-317. DOI: 10.1080/19388070802433206

Harlin, R., Murray R. \& Shea, M. (2007). Broadening Teachers' Views of Diversity through Multicultural Book Discussions, Childhood Education, 83(5), 299-303. DOI: $10.1080 / 00094056.2007 .10522936$ 
Hollander, S. A. (2001). Taking it Personally: The Role of Memoirs in Teacher Education, Electronic fournal for Inclusive Education, 1(4), 1-7.

https://corescholar.libraries.wright.edu/cgi/viewcontent.cgi?

article $=1034 \&$ context $=$ ejie $(2019.08 .20$.)

Jeney, É. (2012). Nyitott könyv - Irodalom, terápia, elmélet. Balassi Kiadó.

Kesler, T. (2011). Expanding Pre-Service Teachers' Conceptions of Texts, Readers, and Response Through Multimodal Response. Language and Literacy, 13(1), 72-94. DOI: 10.20360/G2001V

Komenczi, B. (2009). Elektronikus tanulási környezetek. Gondolat Kiadó.

Kooy, M. (2006a). Telling Stories in Book Clubs: Women Teachers and Professional Development. Kindle Edition.

Kooy, M. (2006b). Telling Stories of novice teachers: Constructing teacher knowledge in book clubs. Teaching and Teacher Education, 22(6), 661-674.

DOI: $10.1016 /$ j.tate.2006.03.010

Lévai, D. (2014). A pedagógus kompetenciái az online tanulási környezetben zajló tanulási-tanítási folyamat során. ELTE Eötvös Kiadó.

http://www.eltereader.hu/media/2015/03/Levai_D_A-

_pedagogus_kompetenciai.pdf

Marable, M. A., Leavitt-Noble, K. \& Grande, M. (2010). Book talks in special education methods courses: Using literature to influence, inspire, and prepare teacher candidates. Teacher Education \& special Education, 33(2), 143-154. DOI: $10.1177 / 0888406409360013$

Mensah, F. M. (2009). Confronting Assumptions, Biases, and Stereotypes in Preservice Teachers' Conceptualizations of Science Teaching through the Use of Book Club. Journal of Research in Science Teaching, 46(9), 1041-1066. DOI: 10.1002/tea.20299

Moore, F. M. (2008). Preparing Elementary Preservice Teachers for Urban Elementary Science Classrooms: Challenging Cultural Biases Toward Diverse Students. Journal of Science Teacher Education, 19(1), 85-109.

DOI: $10.1007 / \mathrm{s} 10$ 972-007-9083-2

Mosley, M. (2010): 'That really hit me hard': moving beyond passive anti-racism to engage with critical race literacy pedagogy. Race Ethnicity and Education, 13(4), 449-471. DOI: $10.1080 / 13613324.2010 .488902$

Mosley, M. \& Rogers R. (2011). Inhabiting the 'tragic gap': preservice teachers practicing racial literacy. Teaching Education, 22(3), 303-324.

DOI: $10.1080 / 10476210.2010 .518704$

Nahalka, I. (2002). Hogyan alakul ki a tudás a gyerekekben. Konstruktivizmus és pedagógia. Nemzeti Tankönyvkiadó. 
Pethőné Nagy, Cs. (2005). Módszertani kézikönyv. Korona Kiadó.

Raphael, T. E. \& McMahon, S. I. (1994). Book Club: An Alternative Framework for Reading Instruction. The Reading Teacher, 48(2), 102-116.

DOI: $10.1598 / R T .48 .2 .1$

Robertson, M. K. \& Smith, J. M. (2017). Exploring one preservice teacher's emerging pedagogical beliefs during an online book club. International fournal of Technology in Teaching and Learning, 13(2), 78-90.

https://www.researchgate.net/publication/328 295217_Exploring_one_preservi ce_teacher's_emerging_pedagogical_beliefs_during_an_online_book_club/ link/5bc524efa6fdcc03c788c400/download (2019. 08. 20.)

Rogers, R. \& Mosley, M. (2008). A critical discourse analysis of racial literacy in teacher education. Linguistics and Education, 19(2), 107-131.

DOI: 10.1016/j.linged.2008.02.002

Rosenblatt, L. M. (1988). Writing and reading: The Transactional Theory. New York University, Center for the Study of Reading.

https://www.ideals.illinois.edu/bitstream/handle/2142/18 044/ctrstreadtechrepv 01 988i00 416_opt.pdf (2019. 06. 24.)

Scheffel, T., Cameron, C., Dolmage, L., Johnston, M., Lapensee, J., Solymar, K., Speedie, E. \& Wills, M. (2018). A Collaborative Children's Literature Book Club for Teacher Candidates. Reading Horizons, 57(1), 1-14. https://scholarworks.wmich.edu/ reading_horizons/vol57/iss1/2 (2019. 06. 24.)

Schön, D. A. (1983). The Reflective Practitioner - How Professionals Think in Action. Basic Books.

Searle, D. (1984). Scaffolding: Who's building whose building? Language Arts, 61(5), 480-483.

Skerrett, A. (2010). Lolita, Facebook, and the Third Space of Literacy Teacher Education. Educational Studies, 46(5), 67-84. DOI: 10.1080/0 0131940903480233

Smagorinsky, P., Clayton, C. M. \& Johnson, L. L. (2015). Distributed Scaffolding in a Service-Learning Course. Theory Into Practice, 54(1), 71-78.

DOI: $10.1080 / 00405841.2015 .977665$

Smagorinsky, P. \& O'Donnell-Allen, C. (1998). Reading as mediated and mediating action: Composing meaning for literature through multimedia interpretive texts. Reading Research Quarterly,33(2), 198-226. DOI: 10.1598/RRQ.33.2.3

Stanulis, R. N. (1999). Adolescent literature as Virtual Experience for Training Middle School Teachers, Middle School fournal, 31(1), 36-40.

DOI: 10.1080/00 940 771.1999.11494607 
Stover, K., Yearta, L. \& Harris, C. (2016). Experiential Learning for Preservice Teachers: Digital Book Clubs With Third Graders, Journal of Digital Learning in Teacher Education, 32(1), 5-12. DOI: 10.1080/21532 974.2015.1055013

Szivák, J. (1998). Tanulásszervezés In Falus, I. (Ed.), Didaktika (pp. 418-434). Nemzeti Tankönyvkiadó.

Szivák, J. (2014). Reflektív elméletek, reflektív gyakorlatok. ELTE Eötvös Kiadó.

Wood, D. J., Bruner, J. \& Ross, G. (1976). The role of tutoring in problem solving. Journal of Child Psychology and Psychiatry, 17(2), 89-100.

DOI: 10.1111/j.1469-7610.1976.tb00381.x

\section{The professional book club as a unique learning environment for teacher training}

Various forms of shared reading analysis, including book clubs, provide an excellent opportunity to support the continuous professional development of teachers at any stage: to connect with their own inner contents and thoughts, to gain insight into their emotional response to specific pedagogical situations or questions, to discover roots of their behaviours and attitudes, and to start to create common meanings and explanations by sharing this insights and views.

This paper first presents the methodology of book clubs and its elements, then examines professional book clubs as a unique learning environment with specific, progressive elements, which also appears in teacher education, summarizing the results of sixteen studies published in the international literature in the last twenty years. Our study highlights that this learning environment is student-centered, provides opportunities for common knowledge building, takes into account the role of emotions and motivation in professional development, helps build horizontal relationships between knowledge elements, the learning environment and the wider social environment, and finally, that it can successfully support the professional development of student teachers.

Keywords: book club, learning environment, teacher training, professional development 